Rev. Mus. Argentino Cienc. Nat., n.s.

11(1): 7-14, 2009

Buenos Aires, ISSN 1514-5158

\title{
Do native grazers from Patagonia, Argentina, consume the invasive kelp Undaria pinnatifida?
}

\author{
S. Valeria TESO ${ }^{1}$, Gregorio BIGATTI2 ${ }^{2}$ Graciela N. CASAS ${ }^{2}$, M. Luz PIRIZ ${ }^{2}$ \\ \& Pablo E. PENCHASZADEH ${ }^{1}$
}

\begin{abstract}
${ }^{1}$ Museo Argentino de Ciencias Naturales-CONICET, Av. Angel Gallardo 470, 1045 Buenos Aires, Argentina, valeteso@macn.gov.ar. ${ }^{2}$ Centro Nacional Patagónico-CONICET, Boulevard Brown 2825, 9120 Puerto Madryn, Argentina.
\end{abstract}

\begin{abstract}
The invasive kelp Undaria pinnatifida (Phaeophyceae, Laminariales) was first reported in Golfo Nuevo in 1992 and since then it has spread widely over more than $170 \mathrm{~km}$, all along the northern Patagonian coast, Argentina. Field observations in the region have indicated the potential role of invertebrate grazers, like the sea urchins Arbacia dufresnii and Pseudechinus magellanicus and the gastropod Tegula patagonica, in controlling algal density. Laboratory experiments were conducted to ascertain whether, and if so, to what extent these grazers actually feed on the algae. The studied sea urchins fed on the alga, whereas the snail scraped off biofouling adhered to its surface. Higher densities of grazers were observed on the kelp during summer and might be attributed to increasing in metabolism with increasing temperature, and degradation of blades and sporophylls, which possibly increase their palatability.
\end{abstract}

Key words: Arbacia dufresnii, feeding behavior, grazing, invasive species, Pseudechinus magellanicus, Tegula patagonica

Resumen: ¿Pueden los pastoreadores nativos de Patagonia, Argentina, consumir al alga invasora Undaria pinnatifida?. El alga invasora Undaria pinnatifida (Phaeophyceae, Laminariales) fue reportada por primera vez en Golfo Nuevo en 1992, dispersándose ampliamente a lo largo de $170 \mathrm{~km}$ de costa en el norte de la Patagonia, Argentina. Observaciones de campo hechas en los erizos de mar Arbacia dufresnii y Pseudechinus magellanicus y en el gasterópodo Tegula patagonica evidenciaron que son posibles consumidores de Undaria pinnatifida en la población local. Se realizaron experimentos de laboratorio con el objetivo de probar si estos pastoreadores eran capaces de consumir el alga. Los erizos de mar estudiados consumen el alga, mientras que el gasterópodo ramonea los epibiontes presentes sobre su superficie. Altas densidades de ramoneadores fueron encontradas sobre el alga durante el verano y podrían ser atribuidas a un aumento del su metabolismo con el aumento de la temperatura y a la degradación de las láminas y esporofilos, lo cual posiblemente aumente la palatabilidad del alga.

Palabras clave: Arbacia dufresnii; comportamiento alimenticio; ramoneo; alga invasora; Pseudechinus magellanicus, Tegula patagonica

\section{INTRODUCTION}

The invasive kelp Undaria pinnatifida (Harvey) (Phaeophyceae, Laminariales) was first found in 1992 in Golfo Nuevo, Patagonia, Argentina, and since then it has spread widely over more than $170 \mathrm{~km}$ along the northern Patagonian coast (Piriz \& Casas, 1994; Casas \& Piriz, 1996; Casas, 2005). In Golfo Nuevo, U. pinnatifida (hereafter referred to as Undaria) is found at depths from 2 to $20 \mathrm{~m}$ and was able to invade all kinds of hard substrata with different dispersal strategies. Young and mature sporophytes are simultaneously present suggesting a constant recruitment pattern. Its introduction into the gulf via ballast water could have been facilitated by the microscopic stage occurring in the life cy- cle (Torres et al., 2004). Sporophytes are more abundant between winter and the end of spring and less abundant in summer, in association with warmer seawater temperatures (Casas \& Piriz, 1996; Casas, 2005).

It has been proposed that the successful settlement and dispersal of Undaria would be favored by the presence of disturbed substrata (Valentine \& Johnson, 2003; Valentine \& Johnson, 2005a, b), but little is known about the factors involved in this disturbance.

In this sense, grazing has been suggested as playing a major role on the basis that herbivores would produce wide areas of barren substrates suitable of being colonized by the kelp and facilitating its dispersal (Sinner et al., 2000). 


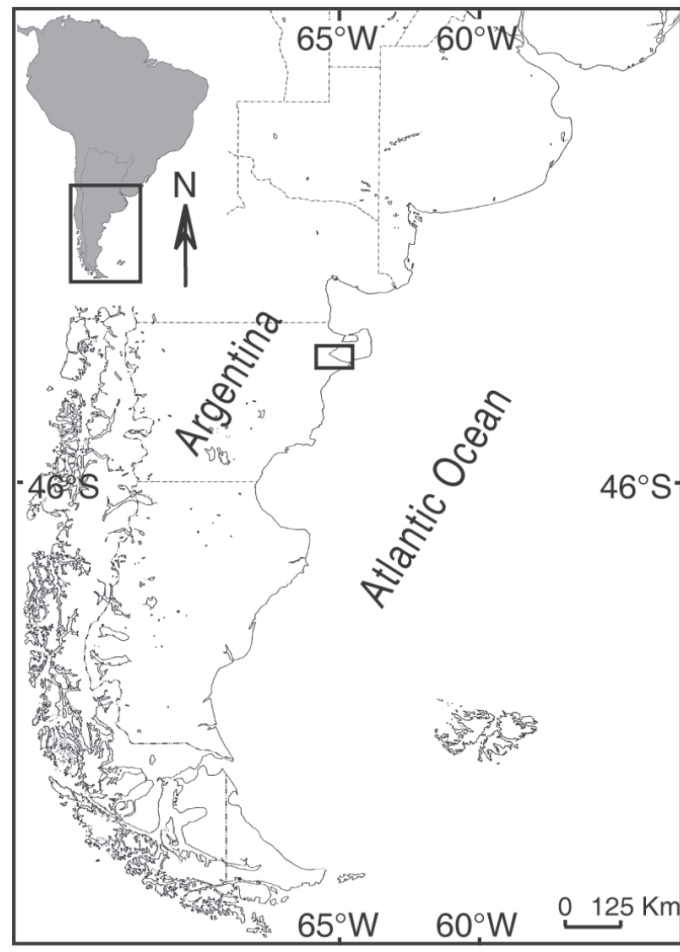

The most frequent animal groups grazing on Undaria are sea urchins and gastropods, and to a lesser extent, crabs and fishes. In Tasmania, where Undaria is an invasive species, the sea urchin Heliocidaris erythrogramma has been observed grazing on its blades (Valentine \& Johnson, 2003; Valentine \& Johnson, 2005a, b). In other parts of the world, preferential feeding on Undaria has been reported for the sea urchins Evechinus chloroticus and Strongylocentrotus nudus, the gastropod Turbo smaragdus, and the crab Pugettia producta, which is known to be associated with kelps (Kittaka et al., 1983; Sinner et al., 2000; Thornber et al., 2004). In Golfo Nuevo, Undaria may constitute a potential new food source for local grazers, like the gastropod Tegula patagonica and the sea urchins Arbacia dufresnii and Pseudechinus magellanicus (Orensanz et al., 2002). Whether the local dispersal rate of Undaria is somehow minimized by grazing pressure, is still a possibility to be examined. The objectives of this work were: 1 ) to determine which are the potential local grazers of Undaria in Golfo Nuevo by field observations, and 2) to test under laboratory conditions whether the sea urchins $A$. dufresnii and $P$. magellanicus, and the gastropod T. patagonica actually feed on the alga.

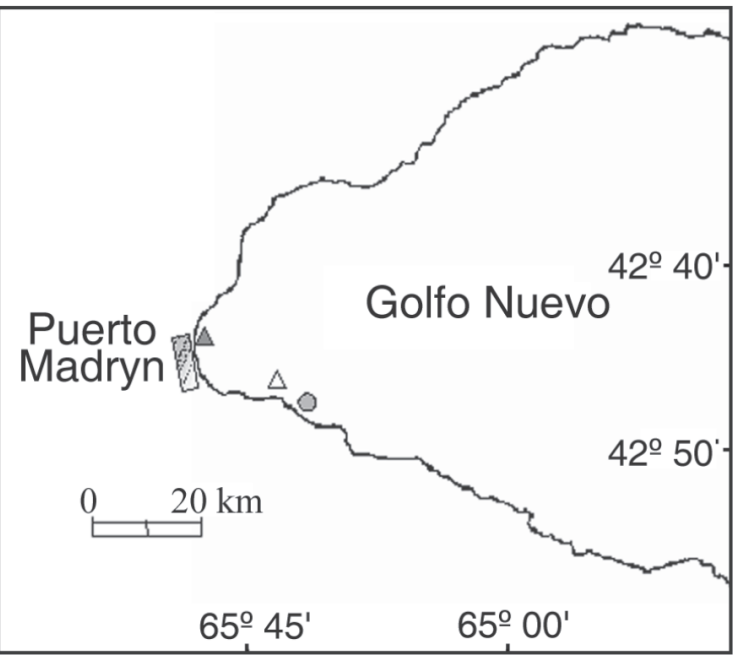

Fig. 1. Location of the study sites: Las Piedras (filled triangle), Punta Este (empty triangle) and the shipwreck «Folias» (filled circle).

\section{MATERIALS AND METHODS}

\section{Field studies}

Field observations of animals grazing on Undaria were conducted by SCUBA diving in three localities at Golfo Nuevo, Patagonia $\left(42^{\circ}\right.$ $45^{\prime} \mathrm{S}-65^{\circ} 55^{\prime} \mathrm{W}$ ), Argentina (Fig. 1). The surveys were performed in November 2003 and September and December 2004, at depths between 4 and 7 meters. Kelps attached to rocky beds covered by gravel and sand were randomly selected and their lengths were measured underwater with a meter.

After conducting a census of the animals found on the kelp, these were collected and sent to the laboratory to be identified and measured with a Vernier caliper.

\section{Laboratory experiments}

Taking into account our field observations previous observations and bibliography, the sea urchins Arbacia dufresnii and Pseudechinus magellanicus and the gastropod Tegula patagonica were used as test animals. They were collected by SCUBA diving in Puerto Madryn, Argentina. Individuals from the same species with similar weight and size were selected for the assays. Animals were kept in 20-1 aquaria with aerated seawater at $11^{\circ} \mathrm{C}$, salinity of $35 \%$, $\mathrm{pH} 8.3$, 


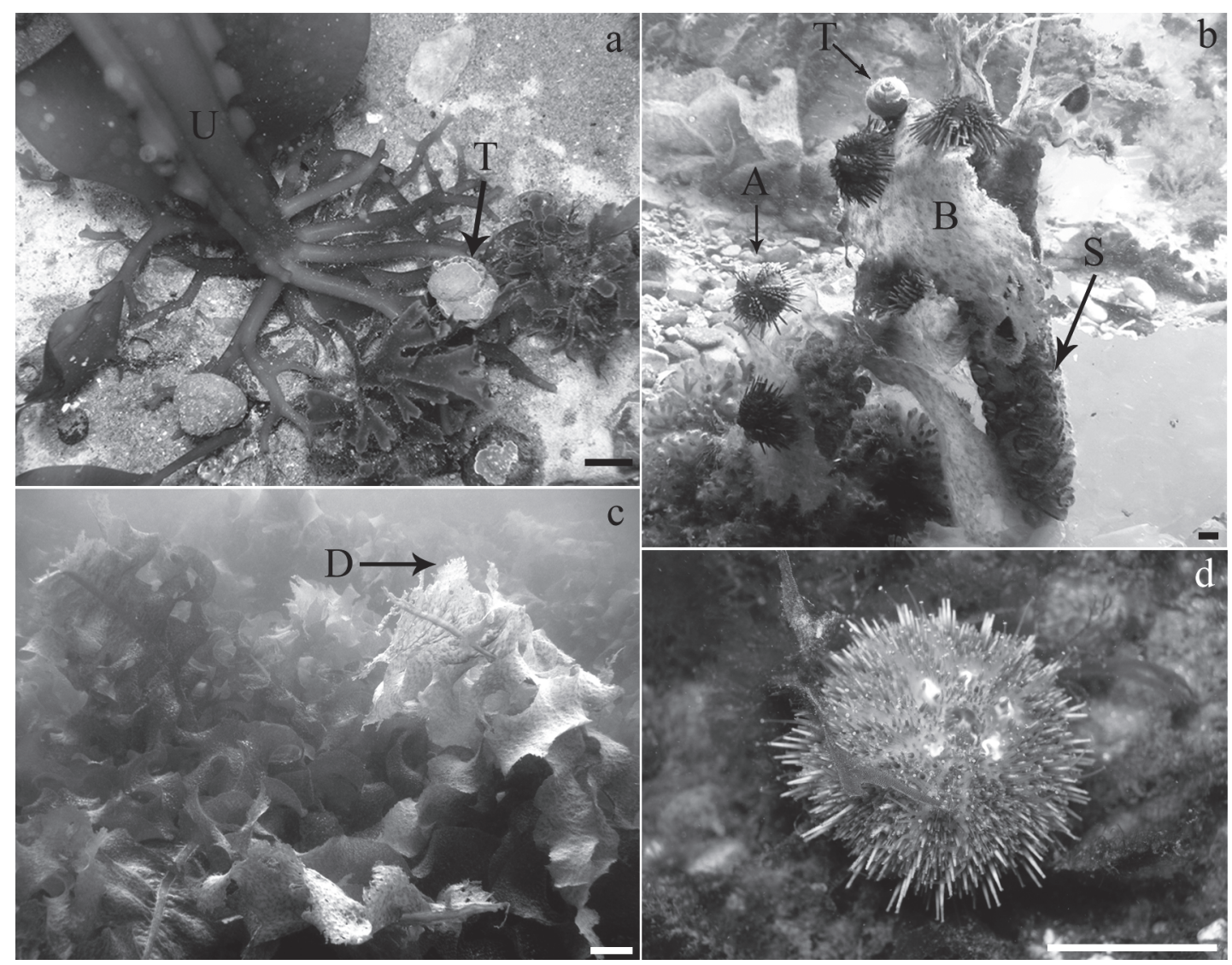

Fig. 2. Grazers upon Undaria pinnatifida from Golfo Nuevo, Patagonia, Argentina. Tegula patagonica on Undaria pinnatifida holdfasts, scale bar $=1 \mathrm{~cm}$ (a); Arbacia dufresnii and T. Patagonica on partially degraded blades of Undaria pinnatifida, scale bar $=1 \mathrm{~cm}(\mathrm{~b})$; blades of Undaria pinnatifida starting degradation, $\mathrm{scale}$ bar $=5 \mathrm{~cm}$ (c); and the cryptic sea urchin Pseudechinus magellanicus, scale bar $=1 \mathrm{~cm}$ (d). (A) Arbacia dufresnii; (B) blade of Undaria pinnatifida; (D) algal degradation; (S) sporophyll of Undaria pinnatifida; (T) Tegula patagonica; (U) Undaria pinnatifida.

and photoperiod 12:12 L: D. They were fed ad libitum for 1 week during the acclimatizing period, and then starved for $72 \mathrm{~h}$ before the start of the experiment. We tested differential feeding on sporophylls (reproductive structures) and blades. Ten specimens of each species were placed in each of three aquaria prepared as described above and containing sporophylls and blades. A fourth aquarium containing only sporophylls and blades was used as a control. After blotting sporophylls and blades with towel paper, their wet weight was recorded twice a week for one month. The experiment was repeated three times using different individuals: in January 2004 (trial A), February 2004 (trial B) and August 2004 (trial C). The size ranges of the animals used in the trials were $14.0-18.3 \mathrm{~mm}, 24.1-28.2 \mathrm{~mm}$ and $11.7-14.1$ mm for P. magellanicus, A. dufresnii and T. patagonica, respectively.

\section{Analysis of gut content and feces}

To confirm kelp consumption by the species used in the experiments, we searched for trumpet hyphae, characteristic cells of Laminariales, in the gut content of 10 individuals of $A$. dufresnii and 10 individuals of $P$. magellanicus. In addition, trumpet hyphae were searched in the feces of 10 live individuals of the three studied species, which had been placed individually in Petri dishes with seawater for $12 \mathrm{~h}$. Examination was made under light microscopy at 40x magnification.

\section{Statistical analysis}

After consumption was confirmed, a parallelism test (Sokal \& Rohlf, 1995) was performed for each species to compare between the wet weights of blades and their control, of sporophylls and their control, and of blades and sporophylls over time. The amount consumed in each trail was 
Table 1. Sampling dates and sites, number of individuals sampled, kelp's information and mean density of each species per plant of grazers collected in Golfo Nuevo, Argentina.

\begin{tabular}{|c|c|c|c|c|c|c|c|}
\hline \multirow[t]{3}{*}{ Date } & \multirow[t]{3}{*}{ Site } & \multirow{2}{*}{\multicolumn{2}{|c|}{ Undaria }} & \multicolumn{4}{|c|}{ Mean density } \\
\hline & & & & \multicolumn{2}{|c|}{ T. patagonica } & \multicolumn{2}{|c|}{ A.dufresnii } \\
\hline & & $\begin{array}{l}\text { Thallus size } \\
\text { (m) }\end{array}$ & $\begin{array}{c}\text { Degradation } \\
(\%)\end{array}$ & blade & sporophyll & blade & sporophyll \\
\hline $11-2003$ & Folias & $0.8-1.2(\mathrm{n}=10)$ & 60 & $10.8 \pm 5.1$ & $1.8 \pm 1.3$ & 0 & 0 \\
\hline 09-2004 & Punta Este & $0.5-1.4(\mathrm{n}=17)$ & 0 & $0.2 \pm 0.4$ & $1.3 \pm 1.9$ & $0.1 \pm 0.3$ & $0.1 \pm 0.2$ \\
\hline $09-2004$ & Las Piedras & $0.2-1.6(\mathrm{n}=14)$ & 0 & $0.3 \pm 1.3$ & $1.3 \pm 1.7$ & $0.1 \pm 0.3$ & $0.8 \pm 0.7$ \\
\hline $12-2004$ & Folias & $0.5-0.9(n=25)$ & 90 & $4.8 \pm 7.4$ & $0.4 \pm 0.7$ & $0.2 \pm 0.5$ & 0 \\
\hline
\end{tabular}

calculated using the equation of Cronin \& Hay (1996): $\left[\left(\mathrm{H}_{0}^{*} \mathrm{C}_{\mathrm{f}} / \mathrm{C}_{0}\right)-\mathrm{H}_{\mathrm{f}}\right]$, where $\mathrm{H}_{0}$ and $\mathrm{H}_{\mathrm{f}}$ were the initial and final wet masses of the algal piece exposed to herbivory respectively, and $\mathrm{C}_{0}$ and $\mathrm{C}_{\mathrm{f}}$ were the initial and final masses of control for autogenic changes. Any negative weights were considered as non-grazing events and analyzed as zero values. This equation provides the amount consumed of each species without autogenic changes in the study period. Then the mean grazing rates (grams/day) for each species in each trail were calculated.

\section{RESULTS}

\section{Field studies}

Arbacia dufresnii and Tegula patagonica were found on both blades and sporophylls of Undaria, they were showing signs of grazing on vegetative tissues (Table 1, Fig. 2 a, b). In contrast, Pseudechinus magellanicus was never detected on the kelp, despite the fact that the species has previously been recorded in the study area (Piriz \& Casas, 2001; Orensanz et al., 2002) and after the census (Fig. 2 d) (Bigatti, pers. obs.; Casas et al., 2008).

The number of grazers was lower in September (Table 1, Fig. 3) than in November and December, at the beginning of algal degradation (Fig. 2 c). No animal was found on kelps at advanced stages of degradation. It is worthwhile to mention the permanent presence of biofouling on Undaria blades.

\section{Laboratory experiments}

\section{Pseudechinus magellanicus}

In trial A, blades were significantly more consumed than sporophylls (test of parallelism $\mathrm{P}<$ 0.0001) (Fig. 4). The amount of blade consumed was $2.2 \mathrm{~g}$ with a grazing rate of $0.06 \mathrm{~g} /$ day. No significant difference in wet weight was found between the consumed sporophylls and the con- trol (test of parallelism $\mathrm{P}=0.7$ ). In trials $\mathrm{B}$ and $\mathrm{C}$ there were no significant differences in wet weight between the consumed blades or sporophylls and their respective controls (tests of parallelism $\mathrm{P}>0.05$ ).

\section{Arbacia dufresnii}

In trials A, B and C blades were significantly more consumed than sporophylls (Fig. 5; test of parallelism $\mathrm{P}<0.0001)$. The amounts of blade consumed were $6.0,3.1$ and $2.3 \mathrm{~g}$ respectively and the grazing rates were $0.2,0.1$ and $0.1 \mathrm{~g} /$ day respectively. No significant differences in wet weight were found between the consumed sporophylls and their controls (tests of parallelism $\mathrm{P}>0.05$ ).

\section{Tegula patagonica}

In trials A, B and C there were no significant differences in wet weight between the consumed sporophylls or blades and their respective controls (test of parallelism $\mathrm{P}>0.05$ ).

\section{Analyses of gut contents and feces}

Trumpet hyphae cells were present in the gut contents and feces of $A$. dufresnii and $P$. magellanicus and absent in the feces of T. patagonica.

\section{DISCUSSION}

The present study is one of the few experimental reports concerning hervibory on Undaria being important to understand its dispersion in non native environments and the changes that it could cause in invaded communities. Grazer densities on sporophyll and blades were higher for T. patagonica than for any of the two sea urchin species. The fact that this gastropod was generally observed scraping the surface of Undaria without the presence of trumpet hyphae cells in the feces suggests that it feeds on biofouling rather than on the alga. 

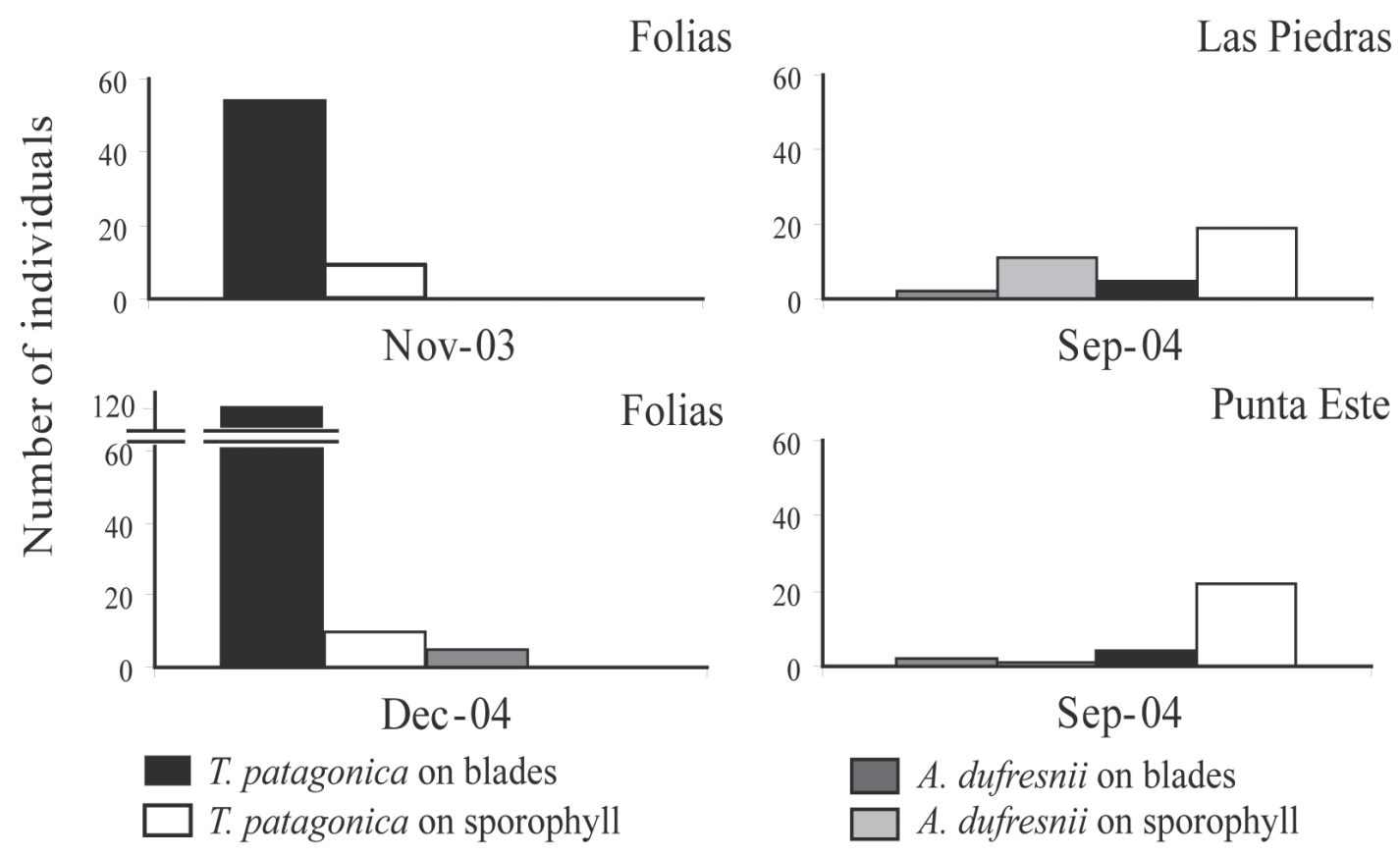

Fig. 3. Number of grazers on Undaria pinnatifida collected from different locations at different dates.

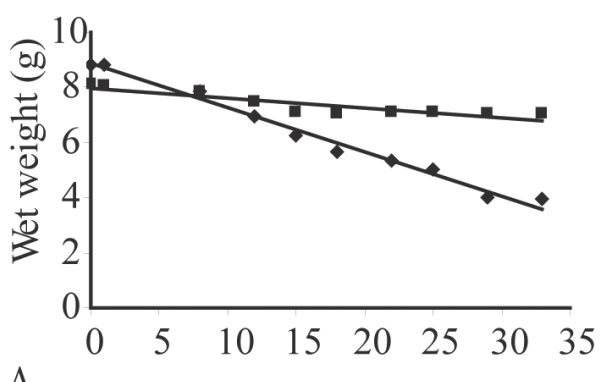

A

Days

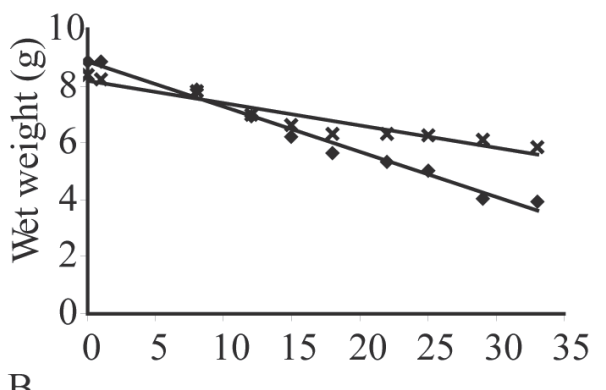

B

Days

Fig. 4. Wet weights (grams) of blade and sporophyll (A); and blade and control (B) recorded over time, using ten individuals of Pseudechinus magellanicus in trial A ( $=$ sporophyll, $\bullet$ blade, $\mathrm{X}=$ control $)$.
In the present study, both $P$. magellanicus and A. dufresnii fed on Undaria blades, but their grazing rates were low. This result may be explained by the feeding behavior of these species. $P$. magellanicus is omnivorous and changes its trophic level depending on the available food resources (Penchaszadeh et al., 2004). Similarly, A. dufresnii is carnivorous where algae are absent, e.g. beds of the bivalve Mytilus edulis platensis d'Orbigny, 1846 at a depth of $50 \mathrm{~m}$ in Argentinean waters (Penchaszadeh \& Lawrence, 1998), and herbivorous when algae constitute the only feeding source.

The finding of a greater number of grazers on Undaria in December (summer) than in spring would be a consequence of increase in metabolism with increasing temperature.

For example, an increased metabolism has been reported during the warmer months (spring-summer) for the sea urchins Sphaerechinus granularis in Brittany, France (Guillou \& Michel, 1994), and Tripneustes gratilla in Southwest Madagascar (Vaitilingon et al., 2003), and for the snail Tegula sp. in Central California (Yee \& Murray, 2004). In addition, blades and sporophylls at early stages of degradation during summer (Casas \& Piriz, 1996) may also ac- 


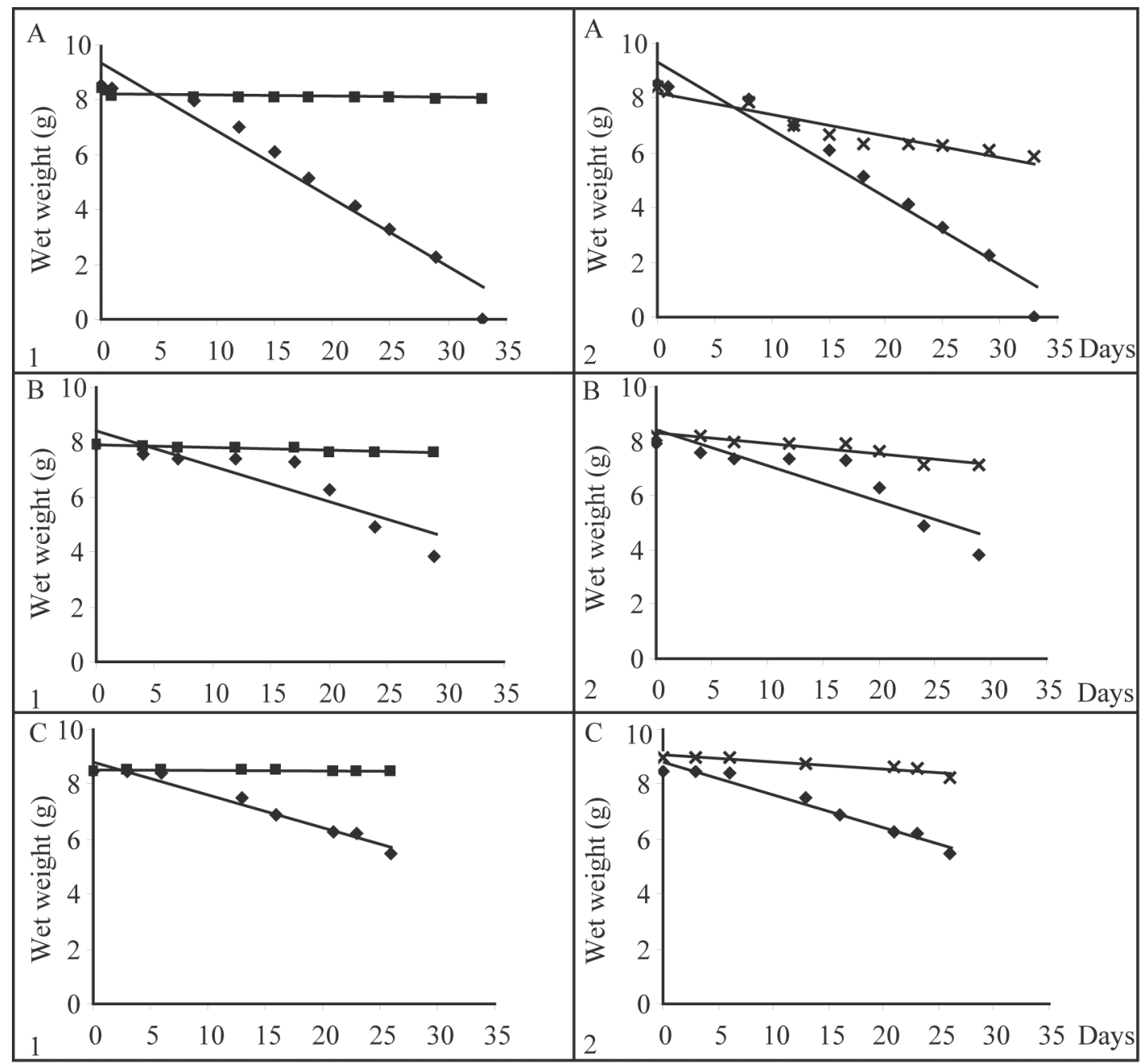

Fig. 5. Wet weights (grams) of blade and sporophyll (1); and blade and control (2) recorded over time, using ten individuals of Arbacia dufresnii in trial A, B and C respectively $(\boldsymbol{\omega}=$ sporophyll, $\bullet=$ blade, $\mathrm{X}=$ control).

count for increased grazing on algae. Renaud et al. (1990) and Cronin \& Hay (1996) have postulated that stress of unpalatable seaweeds increase their susceptibility to generalist herbivores via loss of chemical defenses. However, this statement should be confirmed by further studies of feeding preference. Although Piriz \& Casas (2001) recorded the presence of $P$. magellanicus on Undaria showing signs of being grazed and found kelp remains in the feces, this sea urchin was not observed on Undaria throughout the present study, probably due to its cryptic habit (Marzinelli et al., 2006).

The preference of A. dufresnii and P. magellanicus for blades over sporophylls might result from the greater palatability of vegetative tissues, with a low concentration of phenolic compounds involved in chemical defense, compared to reproductive tissues (Tuomi et al., 1989; Cronin \& Hay, 1996; Van Alstyne et al., 2001). A similar preference has been observed in the crab Pugettia producta grazing on Undaria (Thornber et al., 2004). A greater palatability of vegetative over reproductive tissues was reported for the kelp Alaria marginata Postels \& Ruprecht (Steinberg, 1984).

Undaria is a successful invasive species widespread along the coast of Golfo Nuevo, with a constant recruitment pattern and different dispersal strategies (Casas \& Piriz, 1996; Casas, 2005). Our laboratory experiments show that $A$. dufresnii and P. Magellanicus from Golfo Nuevo 
actually feed on Undaria, but they are unlikely to play a role in the control of the seaweed because the high rates of recruitment and growth of Undaria, but field experiments using grazer exclosures and enclosures are needed to test this hypothesis. The inability of sea urchins to control Undaria has previously been reported for Heliocidaris erythrogramma in Tasmania (Valentine \& Johnson, 2003; Valentine \& Johnson, $2005 \mathrm{a}, \mathrm{b})$ and is now confirmed in Golfo Nuevo in the present paper. This fact must be taken into account at the time of propose conservation policies for the control of the dispersal of Undaria in the study zone.

\section{ACKNOWLEDGEMENTS}

We are grateful to Gabriela Palomo and Eduardo Klein for their useful comments and statistical advice. Thanks to anonymous referees who made useful comments that improved the manuscript. This work was partially supported by PICT 10975, PICT 14419, PIP 5301. S.V.T and G.B were supported by a doctoral fellowship and a postdoctoral fellowship from CONICET, respectively.

\section{BIBLIOGRAPHY}

Casas, G.N. 2005. Biology and ecology of Undaria pinnatifida (Phaeophyceae, Laminariales) in Golfo Nuevo (Chubut, Argentina). Ph.D. Thesis. Universidad Nacional del Sur, Argentina. 234 pp.

Casas, G.N. \& M.L. Piriz. 1996. Surveys of Undaria pinnatifida (Laminariales, Phaeophyta) in Golfo Nuevo, Argentina. Hydrobiologia 326/327: 213-215.

Casas, G.N., M.L. Piriz \& E.R. Parodi. 2008. Population features of the invasive kelp Undaria pinnatifida (Phaeophyceae: Laminariales) in Nuevo Gulf (Patagonia, Argentina). J. Mar. Biol. Assoc. UK 88 (1): 21-28.

Cronin, G. \& M.E. Hay. 1996. Within-plant variation in seaweed palatability and chemical defenses: optimal defense theory versus the growth-differentiation balance hypothesis. Oecologia 105: 361-368.

Guillou, M. \& C. Michel. 1994. The influence of environmental factors on the growth of Sphaerechinus granularis (Lamarck) (Echinodermata: Echinoidea). J. Exp. Mar. Biol. Ecol. 178 (1): 97-111.

Kittaka, J., K. Nishimura, K. Yamada \& Y. Hayakawa. 1983. Experimental analysis on feeding behavior of sea urchin. Marine Fouling 4 (2): 5-9.

Marzinelli, E.M., G. Bigatti, G. Gimenez \& P.E. Penchaszadeh. 2006. Reproduction of the sea urchin Pseudechinus magellanicus (Echinoidea: Temnopleuridae) from Golfo Nuevo, Argentina. Bull. Mar. Sci. 79 (1): 127-136.

Orensanz, J.M., E. Schwindt, G. Pastorino, A. Bortolus, G. Casas, G. Darrigran, R. Elías, J.J. López Gappa,
S. Obenat, M. Pascual, P. Penchaszadeh, M. Piriz, F. Scarabino, E. Spivak \& E. Vallarino. 2002. No longer the pristine confines of the world ocean: a survey of exotic marine in the southwestern Atlantic. Biological Invasions 4: 115-143.

Penchaszadeh, P.E., G. Bigatti \& P. Miloslavich. 2004. Feeding of Pseudechinus magellanicus (Philippi, 1857) (Echinoidea: Temnopleuridae) in the SW Atlantic coast (Argentina). Ophelia 58 (2): 91-99.

Penchaszadeh, P.E. \& J.M. Lawrence. 1998. Arbacia dufresnei (Echinodermata: Echinoidea): A carnivore in Argentinean waters. En: C. Carnevali \& B. Bonasoro (eds), Echinoderm Research pp. 525-530. Balkerna, Roterdam, Holland.

Piriz, M.L. \& G. Casas. 1994. Occurrence of Undaria pinnatifida in Golfo Nuevo, Argentina. Appl. Phycol. Forum 10 (3): 4.

- 2001. Introducción de especies y su impacto en la biodiversidad. El caso Undaria pinnatifida. En: K. Alveal \& T. Antezana (eds), Sustentabilidad de la biodiversidad. Universidad de Concepción, Chile. pp. 679-692.

Renaud, P.E., M.E. Hay \& T.M. Schmitt. 1990. Interactions of plant stress and herbivory: intraspecific variation in the susceptibility of a palatable versus an unpalatable seaweed to sea urchin grazing. Oecologia 82 (2): 217-226.

Sinner, J., B. Forrest \& M. Taylor. 2000. A strategy for managing the Asian kelp Undaria: Final Report. Cawthron Institute, Cawthron Report № 578 Nelson, New Zealand.

Sokal, R. \& F. Rohlf. 1995. Biometry $3^{\text {rd }}$, Freeman \& Co, New York, 88 pp.

Steinberg, P.D. 1984. Algal chemical defense against herbivores: allocation of phenolic compounds in the kelp Alaria marginata. Science 223: 405-407.

Thornber, C.S., B.P. Kinlan, M.H. Graham \& J.J. Stachowicz. 2004. Population ecology of the invasive kelp Undaria pinnatifida in California: environmental and biological controls on demography. Mar. Ecol. Prog. Ser. 268: 69-80.

Torres, A.I., M.N. Gil \& J.L. Esteves. 2004. Nutrient uptake rates by the alien alga Undaria pinnatifida (Phaeophyta) (Nuevo Gulf, Patagonia, Argentina) when exposed to diluted sewage effluent. Hidrobiología 520: 1-6.

Tuomi, J., H. Ivesalo, P. Niemelä, S. Sirén \& V. Jormalainen. 1989. Withinplant variation in phenolic content and toughness of the brow alga Fucus vesiculosus. L. Bot. Marina 32: 505-509.

Vaitilingon, D., R. Rasolofonirina \& M. Jangoux. 2003. Feeding preferences, seasonal gut repletion indices, and diel feeding patterns of the sea urchin Tripneustes gratilla (Echinodermata: Echinoidea) on a coastal habitat off Toliara (Madagascar). Mar. Biol. 143: 451-458.

Valentine, J.P. \& C.R. Johnson. 2003. Establishment of the introduced kelp Undaria pinnatifida in Tasmania depends on disturbance to native algal assemblages. J. Exp. Mar. Biol. Ecol. 295: 63-90. 2005a. Persistence of the exotic kelp Undaria pinnatifida does not depend on sea urchin grazing. Mar. Ecol. Prog. Ser. 285: 43-55. 
- 2005b. Persistence of sea urchin (Heliocidaris erythrogramma) barrens on the east coast of Tasmania: inhibition of macroalgal recovery in the absence of high densities of sea urchins. Bot. Mar. 48 (2): 106-115.

Van Alstyne, K.L., S.L. Whitman \& J.M. Ehlig. 2001. Differences in herbivore preferences, phlorotannin production, and nutritional quality between juvenile and adult tissues from marine brown alga. Mar. Biol. 139: 201-210.

Yee, E.H. \& S.N. Murray. 2004. Effects of temperature on activity, food consumption rates, and gut passage times of seaweed-eating Tegula species (Trochidae) from California. Mar. Biol. 145: 895-903. 